\title{
Change and variability in sea ice during the 2007-2008 Canadian International Polar Year program
}

\author{
David G. Barber • Matthew G. Asplin • \\ Richard L. Raddatz • Lauren M. Candlish • Scot Nickels • \\ Stephanie Meakin • Klaus P. Hochheim • \\ Jennifer V. Lukovich • Ryan J. Galley • \\ Simon J. Prinsenberg
}

Received: 30 January 2012 / Accepted: 17 April 2012 / Published online: 3 May 2012

(C) The Author(s) 2012. This article is published with open access at Springerlink.com

\begin{abstract}
In this paper we describe sea ice change and variability during the Canadian International Polar Year (IPY) program and examine several regional and hemispheric causes of this change. In a companion paper (Barber et al., Climate Change 2012) we present an overview of the consequences of this observed change and variability on ecosystem function, climatically relevant gas exchange, habitats of primary and apex predators, and impacts on northern peoples. Sea ice-themed research projects within the fourth IPY were designed to be among the most diverse international science programs. They greatly enhanced the exchange of Inuit knowledge and scientific ideas across nations and disciplines. This interdisciplinary and cultural exchange helped to explain and communicate the impacts of a transition of the Arctic Ocean and ecosystem to a seasonally ice-free state, the commensurate replacement of perennial with annual sea ice types and the causes and consequences of this globally significant metamorphosis. This paper presents a synthesis of scientific sea ice research and traditional knowledge results from Canadian-led IPY projects between 2007 and 2009. In particular, a summary of sea ice trends, basin-wide and regional, is presented in conjunction with Inuit knowledge of sea ice, gathered from communities in northern Canada. We focus on the recent observed changes in sea ice and discuss some of the causes of this change including atmospheric and oceanic forcing of both dynamic and thermodynamic forcing on the ice. Pertinent results include: 1) In the Amundsen Gulf, at the western end of the Northwest Passage, open water persists longer than normal and winter sea ice is thinner and more mobile. 2) Large areas of summer sea ice are becoming heavily decayed during summer and can be broken up by longperiod waves being generated in the now extensive open water areas of the Chukchi Sea. 3)
\end{abstract}

D. G. Barber $(\bowtie) \cdot$ M. G. Asplin • R. L. Raddatz • L. M. Candlish • K. P. Hochheim • J. V. Lukovich •

R. J. Galley

Centre for Earth Observation Science, Faculty of Environment, University of Manitoba,

460 Wallace Building, Winnipeg, MB, Canada R3T 2N2

e-mail: dbarber@cc.umanitoba.ca

S. Nickels $\cdot$ S. Meakin

Inuit Tapiriit Kanatami, Inuit Knowledge Centre, Suite 1101-75 Albert, Ottawa, ON, Canada K1P 5E7

S. J. Prinsenberg

Bedford Institute of Oceanography, Fisheries and Oceans, Halifax, NS, Canada 
Cyclones play an important role in flaw leads - regions of open water between pack ice and land-fast ice. They delay the formation of new ice and the growth of multi-year ice. 4) Feedbacks involving the increased period of open water, long-period wave generation, increased openocean roughness, and the precipitation of autumn snow are all partially responsible for the observed reduction in multiyear sea ice. 5) The atmosphere is observed as remaining generally stable throughout the winter, preventing vertical entrainment of moisture above the surface.

\section{Introduction and rationale}

The Anthropocene is a time of extraordinary change in the Arctic. It has experienced unprecedented variability in both the rates and magnitudes of change in the cryosphere, atmosphere and lithosphere, dependent also on ecosystem functioning, increased industrial development, and concomitant globalization of local economies. These changes are challenging Canada's ability to respond as a polar nation and to develop a coordinated and scientifically-informed policy for the Arctic.

It is becoming increasingly clear that the predictions from General Circulation Models (GCMs), made 30 years ago (e.g. Hansen et al. 1983), are now being realized. The Arctic is now witnessing the first and strongest signs of global warming. Satellite data show a decrease in September sea ice extent of about 10 percent per decade since the late 1970 s, with a remarkable 65 percent loss in 2007 alone and another equivalent decline in 2011 (NSIDC 2011). Increased cyclogenesis in the Northern Hemisphere is accelerating storminess, shoreline erosion, and the inflow of warm Atlantic water into the Arctic Basin (Inoue and Hori 2011). On land, a significant increase in temperature has wide-ranging effects on glaciers and permafrost, lake ice-cover and ice shelves (IPCC 2007) The flow of Siberian Arctic rivers is increasing as a result of the accelerated hydrological cycle (Lammers et al. 2001). The accelerated melting and seaward movement of the Greenland ice cap have also increased the freshwater flux to the ocean and complicated freshwater marine coupling in surrounding oceans (Segtnan et al. 2011). Warming and degradation of permafrost have been observed throughout the circumpolar Arctic. Large reserves of methane may be released into the atmosphere, thereby providing for an enhanced greenhouse atmosphere. These recent changes strongly support the notion that the Arctic is warming much faster than predicted by even the most pessimistic numerical simulations (IPCC 2007). All indications are that the Arctic climate is on its way to a new equilibrium. The speed of this transition is unlike anything we have seen within the Anthropocene and is most likely a result of anthropogenic forcing of the atmosphere (Kinnard et al. 2011).

Throughout this, and the companion paper (Barber et al. 2012), we investigate the concept of an 'icescape'. To do this we rely on an analogous term - the 'landscape', which is well defined in the academic literature. Scientists have spent thousands of years trying to understand the myriad manifestations of landscape, relating the physical processes which give rise to its structure and to how people live within or manipulate landscapes (e.g., landscape architecture). In the Arctic, the Inuit have lived in and on the icescape, have used it for travel and cultural exchange for many centuries. Their traditional knowledge system represents knowledge gained through experiences and observations over the lifetime of many different individuals. Each of the knowledge systems (i.e., traditional knowledge and western science) has studied icescapes extensively. We use this term 'icescape' throughout what follows, and in particular examine the interface between western science and Inuvialuit knowledge as they pertain to understanding how these 'icescapes' function.

The objectives of this paper are to provide an overview and summary of research results from several Canadian-led IPY projects that contain a significant component of sea ice research 
and that specifically focus on the 'causes' of the observed change and variability in sea ice. The largest IPY project dedicated to sea ice research was the Circumpolar Flaw Lead System Study (IPY-CFL) which focused on the large flaw lead in the southern Beaufort Sea and Amundsen Gulf (Barber et al. 2010). The IPY-CFL study represents the first time that an overwintering research icebreaker remained mobile in a flaw lead polynya, and afforded the opportunity to study ice evolution in the area over an entire sea ice annual cycle. Results are also presented from the IPY project 'Variability and Change in the Canadian Cryosphere', which categorized changes in sea ice and snow cover in the Canadian Archipelago, and the 'THORPEX Arctic Weather and Environmental Prediction Initiative' a long-term research program, led by the World Meteorological Organization, that strives to improve the accuracy of weather and environmental prediction. Throughout the Canadian IPY program, both western science and traditional knowledge were acknowledged as complementary knowledge systems by which we can understand the mechanisms and consequences of these changes. In what follows, we summarize new knowledge gained on the causes of sea ice change and variability. The data were collected from both western science and traditional knowledge through interviews, and were a direct result of Canada's participation in the International Polar Year (IPY).

\section{Traditional knowledge of sea ice}

The IPY-CFL project was predicated around the concept of 'two ways of knowing' (Barber and Barber 2009). This is a concept which recognizes that there are two equally valid approaches of obtaining knowledge about the Arctic environment that can assist us in understanding the impacts of climate change on the flaw lead system. Previous research within the Inuvialuit Settlement Region (Fig. 1) has shown that Inuvialuit are already witnessing and experiencing the impacts of climate change. The long history of occupation in this region provides the opportunity to query the population for visible changes in the sea icescape, weather patterns, animal movements, and how these changes have affected their

Fig. 1 The Circumpolar Flaw Lead System Study area and Inuvialuit communities. The grey dashed line depicts the approximate area of the Cape Bathurst flaw lead polynya system. Note: Holman can also be referred to as Ulukhaktuk

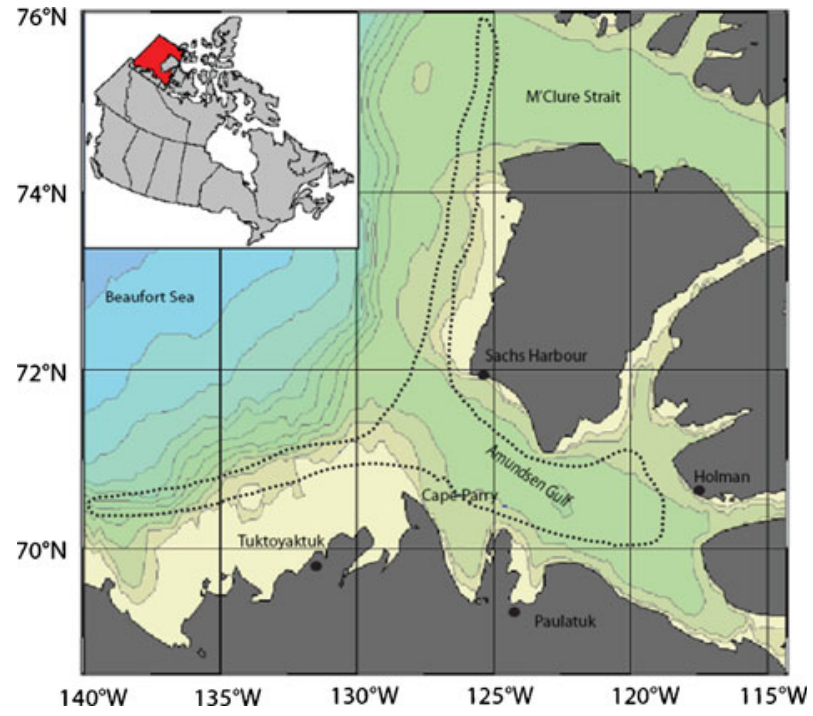


culture and environment. A key component of the IPY-CFL project was a traditional knowledge study that was used to document Inuvialuit cultural knowledge and use of the sea ice (cultural icescape), and observations related to climate change. Members of the IPY-CFL project (CFL Team 10) interviewed a total of 49 Inuvialuit (community members from Paulatuk, Sachs Harbour, and Ulukhaktok, Northwest Territories; Fig. 1) to document their knowledge of the sea ice and the factors affecting sea ice change. These 49 community members together cumulate some 2290 years of experience on the land, with a mean experience of $\sim 47.7$ years per individual. The team also examined aspects of how change in the sea ice affects marine ecosystems and marine resources and how the Inuvialuit are adapting to such changes.

The 49 interviewees from the three communities discussed the importance of sea ice, including the important characteristics of the Cape Bathurst flaw lead and the critical role it plays for wildlife and Inuvialuit subsistence hunting. Open water areas and cracks in the ice (leads) are also important areas for seals, polar bears, and humans. Seals use the ridges to build their dens, and swim in the open water to feed. Polar bears will follow cracks in the ice to access seals. Inuit Hunters use pressure ridges to hunt from and set their nets. Further details of this are included in the companion paper on the consequences of sea ice change during the IPY (Barber et al. 2012).

The most common observation reported by interviewees from all communities is the presence of less sea ice and more open water. Throughout the winter, there are now observed to be larger and more frequent areas of open water that in the past typically remained frozen. Open water is also being found closer than usual to the shore suggesting that the formation of fast ice has changed. Interviewees from the community of Paulatuk indicated that open water areas are typically found north of Cape Parry and Pearce Point during October and November, while in the waters near Paulatuk, there will not usually be open water areas in the bay during these months, except for cracks along the coastline that will open after freeze-up occurs. Community members from Sachs Harbour also note that freeze-up occurs about a month later than it did 20-30 years ago.

Interviewees state that the strength of local ocean currents and winds dictate open water conditions and the size and frequency of leads and cracks in the sea ice. Near Cape Parry for example, currents influence the formation of leads and cracks in the ice. Sea ice conditions are strongly controlled by the interaction of winds with existing open water or cracks in the ice. Strong winds are identified as a major factor for increasing the number of cracks and leads forming in the sea ice. This occurs even during times when ice is not normally as prone to cracking (i.e., January, February). Wind direction was also identified as a key forcing on the size of the sea ice leads.

More open water and cracks in the ice can have serious implications for travel and hunting, with multiple subsequent cultural, economic, and physical effects. Interviewees discussed how it is difficult to go hunting out in the ocean when it's open water. Interviewees from Sachs Harbour mentioned that the practice of travelling far out into Amundsen Gulf on the sea ice was no longer considered safe. The increase in the number of open water areas and sea ice leads has also affected animals: polar bears, for example, are more difficult to find. The increased size of open water areas is also making it more difficult for polar bears to access seals.

Community members have also reported changes in the nature of pressure ridges around their communities. There are fewer pressure ridges, and they are not as thick or as high as in the past. Warmer temperatures appear to be affecting how ice forms, and ice is not subject to the conditions required for it to thicken as it once did, causing some areas to have more rubble ice and preventing multi-year ice build-up. The ridges melt faster because they are made from 
smaller chunks of ice that are easier to break off and pile up. High winds will break up thinner ice causing higher piles of rubble that are not navigable.

The formation of ridges and the size of ice pile-ups are also dependent on wind and current strength. In Ulukhaktok, changing tides are also thought to influence the formation of the ice into pressure ridges. Near all three communities (Paulatuk, Sachs Harbour, and Ulukhaktok), there are spots known to typically have open water, cracks, or pressure ridges. Open water will be found outside of bay areas in the deeper water and, as well, in shallower water characterized by strong currents. In Paulatuk, it was also discussed how shallower areas will have more ice piles. This complements observations in Sachs Harbour showing greater movement of ice in shallow and open areas.

Residents of each of the three communities mentioned that the impacts of rubble ice on travel are great. Community members have had to change their travel routes or abandon travel on the ice altogether because it is no longer smooth. It can be very dangerous for travellers on the ice, even in the late winter, when ice was typically solid (e.g., January-March). The rubble ice is also known to affect the animals. Polar bears may have a more difficult time accessing seals in rubble ice areas. It is also difficult for the bears to penetrate the ice during hunting.

Other IPY projects involving northern community members in traditional knowledge-based studies have reported similar observations. The project titled 'Inuit Sea Ice and Occupancy Project' (ISIUOP) looked at Nunavut and Nunavik communities in the central and eastern Canadian Arctic to document and map local sea ice expertise and experiences. The study characterized the seasonal sea ice conditions, the extent and areas of sea ice use, the nature and location of notable sea ice hazards, key harvesting areas, and traditional and current ice (and land) routes. The observations revealed similar trends, with sea ice freezing later in the fall and the break-up of sea ice occurring earlier in the spring, with the sea ice being generally less reliable and predictable. They also noted that the degree to which the changes are affecting activities on the sea ice varies from community to community and in some instances from hunter to hunter. Consequently, there have been significant changes in the layout of sea ice trails and harvesting areas used by the communities.

\section{Western science knowledge of sea ice}

The western science approach to two way of knowing (Barber and Barber 2009) also produced many new insights into the cause of sea ice change and variability. Sea ice acts as an insulating layer between the atmosphere and ocean by providing a barrier to heat and mass transport across the ocean-sea ice-atmosphere (OSA) interface. It is the albedo (reflectivity) of the sea icescape that renders it an important component in the earth-ocean-atmosphere system. Sea ice reflects up to $50 \%$ of incoming solar radiation (the albedo is $\sim 0.5$ ) while snow-covered sea ice can reflect up to $90 \%$ of incoming solar radiation (with an albedo of $\sim 0.9$ ). The high reflectivity of sea ice sustains both cold Arctic temperatures during sunlit seasons as well as the equator-topole temperature gradient that governs hemispheric-scale heat circulation. The dramatic loss of sea ice cover in the Arctic has significant implications for the earth's energy budget. The latter is defined by the balance between incoming and outgoing solar radiation.

Sea ice extent is defined as the area with at least $15 \%$ ice concentration (see NSIDC 2009) based upon the passive microwave satellite record. In the Northern Hemisphere, the maximum extent historically occurs in March when sea ice covers approximately 15 million $\mathrm{km}^{2}$ (Comiso 2003a). The minimum sea ice extent occurs in September when sea ice covers approximately 7 million $\mathrm{km}^{2}$. Sea ice minimum extents in recent years have undergone a dramatic decline during summer. Figure 2 highlights the sea ice minimum extents observed in 1979, 2000, 2005, and 
a

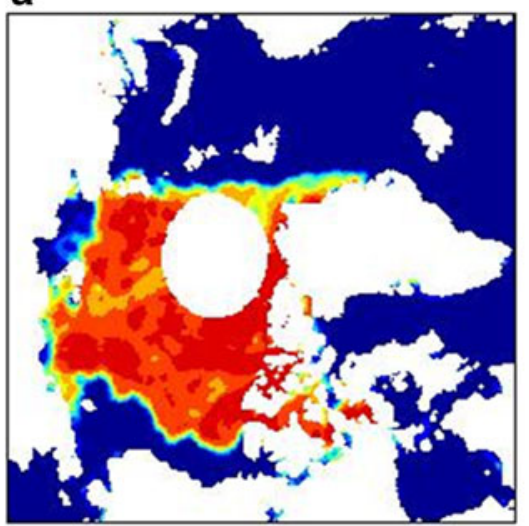

c

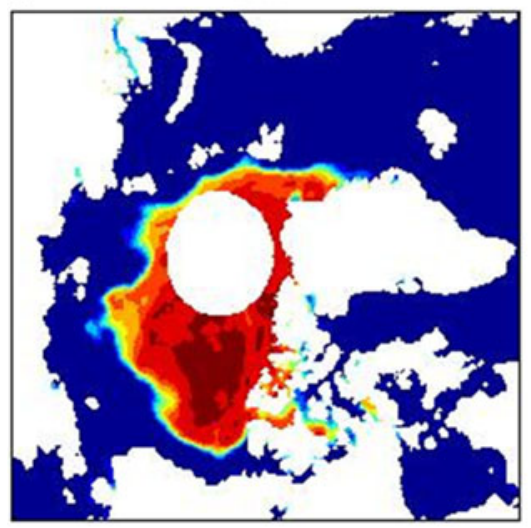

b
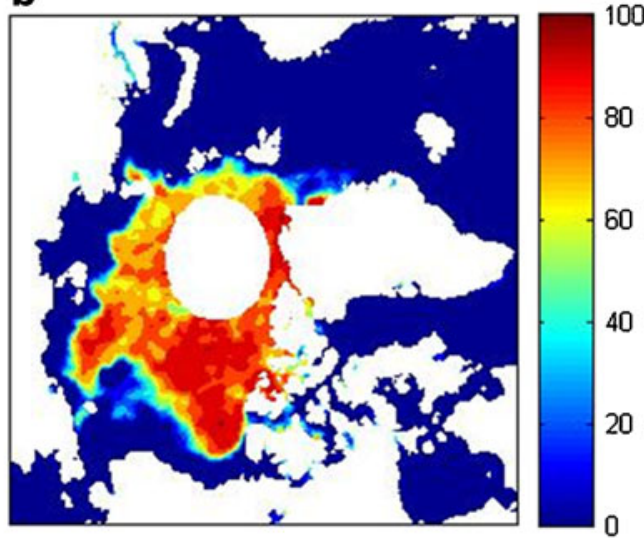

d

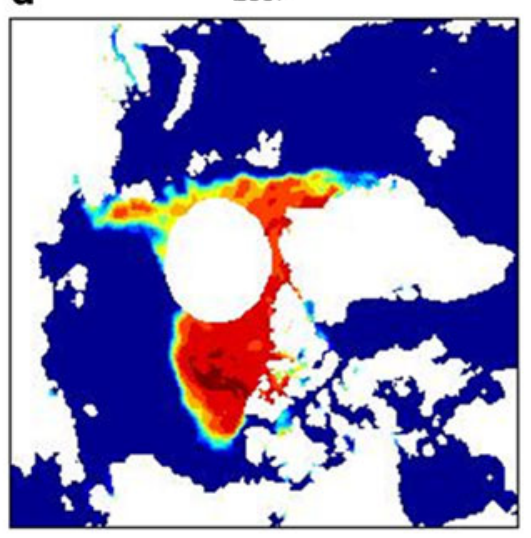

100

80

60

40

20

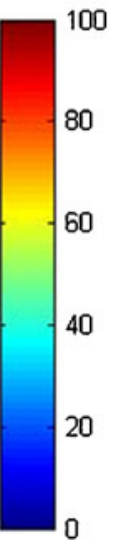

Fig. 2 Sea ice minimum extents (\% sea ice concentration) (a) 1979 (start of the satellite record), (b) 2000, (c) 2005 , and (d) 2007 (record minimum summer sea ice extent). Note: data missing north of $87.5^{\circ} \mathrm{N}$ due to limitations of polar orbiting satellite paths

2007, and contrasts mean sea ice extent from 1979-2000 with low sea ice extents observed in 2000, 005 and 2007.

The investigation of declining summer sea ice extent yields negative trends in annual and seasonal cycles (Fig. 3), with an overall statistically-significant trend of $-42,100 \mathrm{~km}^{2}$ per decade in the yearly averages reported by Parkinson and Cavalieri (2008). When the 20082010 melt seasons are included, the rate of decline jumps to $-81,310 \mathrm{~km}^{2}$ per decade $(-12.4 \%$ per decade) (Maslanik et al. 2011), and this rate may further increase when the 2011 summer minimum extent is included in the trend, as 2011 is about equal to that for 2007 (NSIDC 2011). The most dramatic regional decline in sea ice cover is in the Kara and Barents Seas (Parkinson and Cavalieri 2008), and more recently in the Beaufort and Chukchi Seas (Maslanik et al. 2011).

Accelerated loss of sea ice in the 21 st century has resulted in a significant reduction in ice thickness (Laxon et al. 2003; Yu et al. 2004; Lindsay and Zhang 2005). Previous studies have noted that the most striking decline occurs in marginal ice zones and coastal regions (Deser and Teng 2008; Budikova 2009). Other studies also show regional differences in ice 
Fig. 3 Spatial-temporal trends in sea ice decline for week 37 (early September) during 1979-2010 (units are in standard deviations from normal). Noteworthy is a large negative trend in sea ice cover in the Chukchi, Beaufort, Laptev, and Kara seas. Notable declines are also present in the Canadian Arctic Archipelago, the Barents Sea, and in Fram Strait

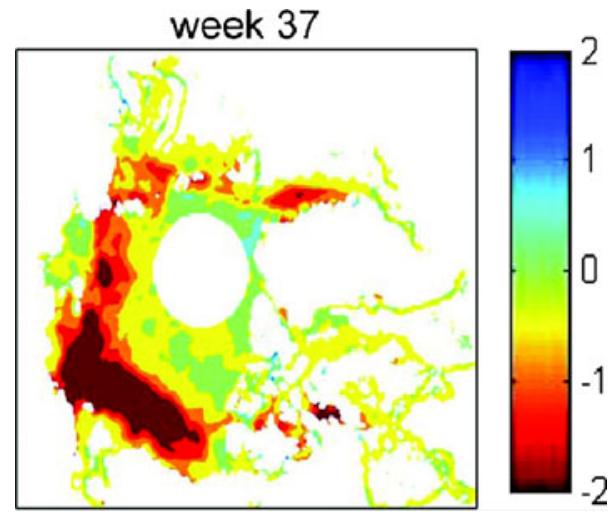

thickness and a significant decline in multi-year ice (Rothrock et al. 1999; Lindsay and Zhang 2005; Comiso 2006; Maslanik et al. 2007; Haas et al. 2008). Observational studies onboard the icebreaker CCGS Amundsen showed that the Beaufort Sea region was characterized by a severely deteriorated ice cover in August 2009 (Barber et al. 2009) that resulted in dramatic ice loss the following summer (2010).

As part of IPY, Tivy et al. (2011) analysed the Canadian Ice Service Digital Archive (CISDA) weekly ice charts covering 1960-2008 for trends and variability in summer sea ice in the Canadian Arctic. They concluded that during 1960-2008 the summer sea ice cover had decreased the most in Hudson Bay, by approximately $11 \%$ per decade. They also found that sea ice extent decreased by approximately $2.9 \%$ per decade in the Canadian Arctic Archipelago, $8.9 \%$ per decade in Baffin Bay and by $5.2 \%$ per decade in the Beaufort Sea. The results from their study provided evidence that the increasing surface air temperature in the Arctic will continue to reduce summer sea ice cover and thereby facilitate increased marine navigation through the Canadian Arctic in the near future.

\subsection{Sea ice conditions in the Canadian Arctic Archipelago}

Recent studies highlight the variability in ice concentrations in the Canadian Arctic Archipelago (CAA) (Agnew et al. 2008; Howell et al. 2009; Barber and Lukovich, 2011). Statistically significant decreases in average September total sea ice area of $8.7 \%$ decade $^{-1}$ are reported by Howell et al. (2009). This is in contrast to statistically non-significant trends reported by Barber and Lukovich (2011). They report changes in sea ice extent in the CAA with values on the order of $-5000 \pm 400 \mathrm{~km}^{2}$ per decade, with the strongest trend observed in October.

September MYI area within the CAA is decreasing at a rate of $6.4 \%$ decade $^{-1}$; however the trend remains statistically nonsignificant due to increasing MYI dynamic import from the Arctic Ocean. (Howell et al. 2009).

The observed reductions in sea ice extent in the CAA are attributed to an increasing melt season length, and sea ice dynamic processes (sea ice flux). The melt season duration within the CAA is increasing significantly at $\sim 7$ days decade ${ }^{-1}$ (Howell et al. 2009). The longest melt season duration on record was reported in 2008 at 129 days in duration (Howell et al. 2009), 13 days longer than the average melt season duration of 116 days (Howell et al. 2008). Investigations of sea ice flux during 2002-2005 demonstrated that maximum ice export/import occurs in the M'Clure Strait, Amundsen Gulf and Lancaster Sound areas, resulting in a net loss of $122 \times 10^{3} \mathrm{~km}^{2}$ of sea ice over September 2002-June 2007 (Agnew et al. 2008). MYI ice will likely continue to be present in the M'Clure Strait and western 
regions of the Northwest Passage during the transition to a summer ice-free Arctic (Howell et al. 2009).

Howell et al. (2010) compares the extreme sea ice minima observed within the CAA during 2007 to that which occurred in 1998. September average sea ice areas were 2.90 and 2.65 standardized anomalies below the historical 1968-1996 climatology for 1998 and 2007 respectively. October sea ice areas for 1998 and 2007 were 4.45 and 3.36 standardized anomalies lower than climatology. The extreme melt in 2007 was attributed to concentrated thermodynamic melting over 1 month (July 2008), whereas 1998 was characterized by a long melt season with above-normal air temperatures persisting in June, September and October. Sea ice dynamics played contrasting roles in both cases. Sea ice dynamics in 1998 inhibited ice replenishment from the Arctic Ocean within the CAA, however they promoted ice replenishment in 2007.

A more detailed look at the sea ice climatology over 1961-2008 (Tivy et al. 2011) was conducted by the Canadian Ice Service and is described in detail in Derksen et al. (2012).

\subsection{Sea ice conditions in Baffin Bay}

Negative sea ice concentration anomalies are present in Baffin Bay in the southern segment during winter and spring and throughout the basin in summer, thereby showing a trend towards decreased seasonal sea ice coverage. Meteorological conditions and ocean currents govern sea ice in Baffin Bay, with maximum ice velocities in the northern portion (Tang and Dunlap 2007). The North Water (NOW) Polynya in northern Baffin Bay allows transfer of heat and radiation between the atmosphere and the ocean. The result is a region of significant biological productivity (NOW 2001). The North Water Polynya expands in March and attains its maximum area in July. During recent years there have been negative trends in sea ice concentration in the northern region of Baffin Bay, suggesting that the polynya is expanding earlier. This is complicated by the formation of ice bridges north of the NOW polynya which hold ice back in the Lincoln Sea. When the ice bridges do not form, the NOW polynya is governed by the export of ice into this region that makes it a marginal ice zone rather than the usual open water of the polynya (Barber et al. 2001). Weekly trends show a maximum reduction in sea ice extent during early November. Annual trends were on the order of $-8000 \pm 2000 \mathrm{~km}^{2}$ per year in Baffin Bay during 1979-2006, with substantial decreases in ice concentrations after 1996 (Parkinson and Cavalieri 2008). Baffin Bay was free of ice by midAugust in 2010, and an ice bridge was formed in Nares Strait in mid-February, 2011, in contrast to the previous five years when Nares Strait was comparatively ice-free.

\subsection{Sea ice conditions in Hudson Bay}

Sea ice in Hudson Bay forms in late October and is typically ice-free $(<15 \%$ ice cover) by August; basal growth rates reach their peak in December and decline from January to March (Saucier et al. 2004). Modelling studies of the Hudson Bay region for the latter part of the 20th century show east-west asymmetry in ice conditions, with maximum growth rates in northwestern Hudson Bay, associated with a polynya in this region, and in Foxe Basin (Saucier et al. 2004). Moreover, in southern Hudson Bay and eastern Foxe Basin, ridging and redistribution (sea ice dynamics) of sea ice are thought to play a more pivotal role than thermodynamics in areas of maximum sea ice concentration and thickness (Saucier et al. 2004). Changes in these ice conditions in Hudson Bay are demonstrated by annual trends over 1979-2006, with values on the order of $-4500 \pm 900 \mathrm{~km}^{2} / \mathrm{a}$; seasonal trends show that the largest decline in sea ice occurred during fall (Parkinson and Cavalieri 2008). In addition, 
trends for ice freeze-up and break-up dates show a tendency towards earlier breakup in James Bay and along the southern shore and western half of Hudson Bay, and later freeze-up in the northeastern regions of Hudson Bay. As noted below, the existence of longer ice-free seasons in Hudson Bay has a negative impact on polar bear populations in this region. Hudson Bay was free of ice by the third week of July 2010, much earlier than usual.

Hochheim and Barber (2010) investigated trends in fall sea ice concentration and sea ice extent in Hudson Bay over 1980-2005. Sea ice concentration anomalies reveal statistically significant trends ranging from $-23.3 \%$ to $-26.9 \%$ per decade using Canadian Ice Service data. Mean sea ice extents based on seasonal ice concentration (SIC) $>80 \%$ have decreased by $1.05 \times 10^{5} \mathrm{~km}^{2}$ to $-1.17 \times 10^{5} \mathrm{~km}^{2}$ in areal coverage for every $1^{\circ} \mathrm{C}$ increase in temperature in late November. Mean decreases in sea ice cover over the satellite record (1980-1995 vs. 1996-2005) ranged from $112,000 \mathrm{~km}^{2}$ to $241,000 \mathrm{~km}^{2}$ depending on the week of the year. Changes in regional surface air temperature during the freeze-up period linked to observed changes in hemispheric teleconnections (Hochheim and Barber 2010).

Hochheim et al. (2011) also investigated spring temperature and sea ice trends. They revealed that spring surface air temperature anomalies surrounding Hudson Bay have increased by 0.26 to $0.30^{\circ} \mathrm{C}$ per decade during 1960-2005. Negative trends in sea ice extent correspond with the positive temperature anomalies. Trends in sea ice concentration ranging from -15.1 to $-20.4 \%$ per decade were observed in western and south-western Hudson Bay. Sea ice extent decreased in Hudson Bay by 8790 to $10,035 \mathrm{~km}^{2}$ per year. Sea ice extents in spring were shown to be highly dependent on both spring and previous fall surface air temperatures surrounding Hudson Bay, and dynamic forcing of sea ice as expressed by the relative vorticity of ice within Hudson Bay (Hochheim et al. 2011).

\subsection{Sea ice conditions in the Beaufort Sea}

The implications of a retreating ice cover for the climatology of the Beaufort Sea region were examined in a recent evaluation of the meteorology of the region showing that air temperatures in the fall increased by more than $6^{\circ} \mathrm{C}$ (Overland 2009). Consistent with this, in August 2009, sea ice in the Beaufort Sea region consisted largely of rotten ice, or floating ice in an advanced stage of disintegration (Barber et al. 2009; NSIDC 2010). Subsequently, this contributed to a significant loss of sea ice during the summer of 2010 (NSIDC 2010) and again in 2011. Indeed, ice charts for the western Arctic illustrated a decline in the distribution of thick multi-year ice in the Beaufort Sea in September 2010. Especially noteworthy was the scarcity of thick MYI, present only as thin bands (red region) dispersed throughout a region of relatively lower concentrations of first-year ice (Fig. 4).

The evolution of the sea ice cover within Amundsen Gulf and the Southern Beaufort Sea was assessed for the IPY-CFL study (01 September 2007-01 September 2008). Sea ice coverage was assessed by ice type using weekly digital ice chart data for the western Arctic obtained from the Canadian Ice Service digital archive. Data was gridded (one pixel $=2 \times 2 \mathrm{~km}$ ) and sea ice concentrations were directly extracted from the CIS data and presented (in tenths of sea ice coverage) for old, thin first-year, new, and total sea ice. Ice charts are prepared by expert interpretation of satellite imagery following CIS classification protocol [Fequet 2002]. For each digital ice chart, the fraction of total, old, first-year (a superset of thick first-year $(>120 \mathrm{~cm})$, medium first-year $(70-120 \mathrm{~cm})$, and thin first-year $(30-70 \mathrm{~cm})$ ), young $(10-30 \mathrm{~cm})$ and new ice $(<10 \mathrm{~cm})$ in each pixel was multiplied by four to obtain the areal coverage (in $\mathrm{km}^{2}$ ) of each ice type in each pixel. Coverage by type in each pixel $(n=159685)$ was summed and divided by the total study area $\left(638740 \mathrm{~km}^{2}\right)$ yielding the fractional coverage of the study area by sea ice type for each weekly chart [Galley et al. 2008; Tivy et al. 2011]. Sea ice lead formation occurred in 


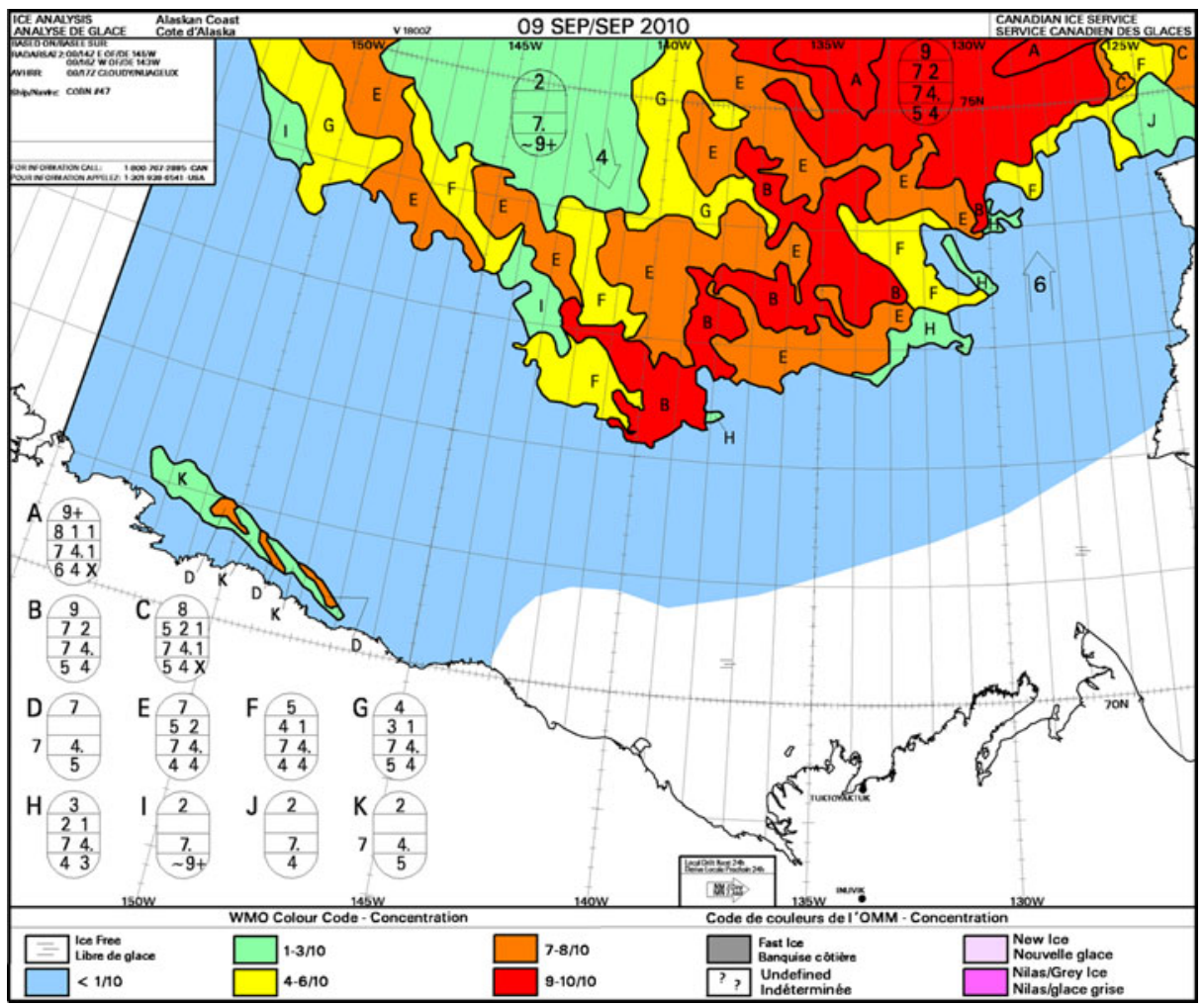

Fig. 4 Canadian Ice Service (CIS) sea ice chart for the Beaufort Sea region for 09 September 2010. Multiyear ice (red region) is interspersed amongst lower ice concentration regions containing heavily decayed firstyear sea ice. Additional information on the interpretation of sea ice symbols and code may be found at: http:// www.ec.gc.ca/glaces-ice/default.asp?lang=En\&n=19CDA64E-1. (Source, Canadian Ice Service)

the CFL study region throughout the winter as revealed by the time series of new and young sea ice (Fig. 5) which showed rapid and substantial increases in fractional coverage after initial fall freeze-up. Substantial lead formation occurred in the first week of January 2008, the middle of February and for much of April and May, all signalled by a spike in the young ice fraction and to a lesser degree by increases in new ice fraction (Fig. 5).

The greatest decline in sea ice concentrations within the Beaufort Sea during the 20072008 IPY were observed in the southern Beaufort Sea (Canadian Sector and north of Alaska) from weeks 33 to 41 (July-August)(Barber et al. 2010). These observations are in agreement with previous studies which have shown that the largest losses in sea ice extent within the Beaufort Sea have occurred during summer and fall. In particular, declines have been calculated on the order of $-10,100 \pm 2,200 \mathrm{~km}^{2}$ per year in the region encompassing the Beaufort Sea and the Arctic Ocean (Parkinson and Cavalieri 2008). The slight increase in ice concentration in the eastern Beaufort Sea and the significant decrease in ice concentration in the western segment of the Beaufort Sea in summer during 1979-2006 was also seen in studies of the connections between ice and atmospheric phenomena (Deser and Teng 2008). Thinning of the Arctic sea ice cover and, in particular, the loss of multi-year ice in the Beaufort Sea was also captured in other studies (Ngheim et al. 2007; Howell et al. 2008; Peterson et al. 2008; Kwok et al. 2009). 
Fig. 5 Flaw lead areas $\left(\mathrm{km}^{2}\right)$ in Amundsen Gulf during the IPY-CFL study year (01 September 2007 - 01 September 2008) estimated using cumulative areas of thin ice types $(\mathrm{FYtn}=$ thin first-year $(30 \mathrm{~cm}+)$, Yng $=$ Young ice $(10-30 \mathrm{~cm})$, New $=$ new sea ice $(0-10 \mathrm{~cm})$

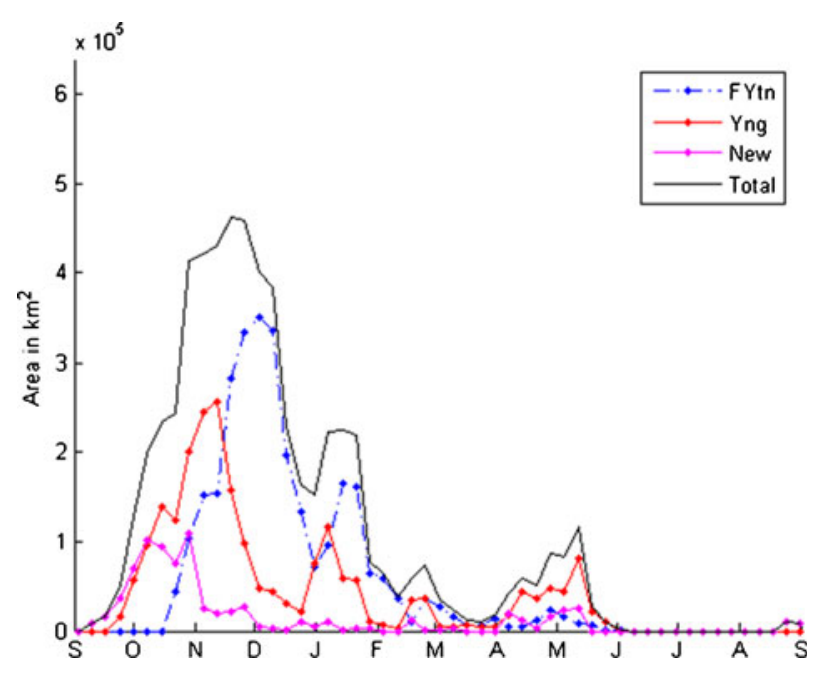

\section{Climate forcing of sea ice}

Climate change is a consequence of both natural and anthropogenic forcing. Increased greenhouse gas loading to the atmosphere has accelerated climate warming in recent decades. Some of the strongest signals are observed in the Arctic and, in particular, in the dramatic loss of sea ice since 1979. The report from the Intergovernmental Panel on Climate Change (IPCC 2007) highlighted the fact that certain elements of the Earth's system, such as sea ice, are subject to abrupt transitions due to the dependence of their transition from the liquid to solid phase on temperature. Increases in surface air temperature ranging from 1 to $3^{\circ} \mathrm{C}$ in the Arctic in the last decade, and an accelerated decline in Arctic sea ice extent and thickness underscore the dramatic impact of warming at high latitudes.

An unprecedented and accelerated change in sea ice in the early part of the 21 st century is referred to as the 'recent Arctic warm period' (Overland et al. 2008). Previous studies have shown that the increase in surface air temperature is responsible for an increase in oceanic heat content and latent heat in Arctic waters and is associated with a decline in sea ice extent (Zhang 2005). Satellite measurements now highlight accelerated warming in the last several decades relative to a 100-year trend, with maximum warming in autumn in the Chukchi and Beaufort Seas (Comiso 2003b). An average increase in the melt season by 10-12 days was also noted. This trend has recently been extended to show that the current decline in sea ice is unprecedented for a period of at least the past 1,450 years, based on paleoclimate reconstructions of the extent of sea ice in the northern hemisphere (Kinnard et al. 2011).

Changes in sea ice are associated with reinforcement of the ice-albedo feedback mechanism that lowers the albedo of the surface cover in the Arctic. Mechanisms responsible include (1) an increase in surface air temperatures over the last several decades, (2) large-scale atmospheric forcing mechanisms and meridional transport that influence an increasingly mobile ice pack in the Arctic, (3) variability in cloudiness and subsequent downwelling radiation (Kay et al. 2008)., and (4) an increase in solar radiation absorption due to an increase in first-year ice (Lindsay and Zhang 2005). Recent studies attribute unprecedented melting on the bottom of the sea ice in the Beaufort Sea in 2007 to increased oceanic heat as a result of increased open water, solar heat input, and advection of ocean heat fluxes poleward through the Bering Strait (Woodgate et al. 2006) thus amplifying the ice-albedo feedback mechanism responsible for 
accelerated ice loss (Perovich et al. 2008). This phenomenon may also contribute to increased areas of open water and heavily decayed first-year ice, termed 'rotten ice' (Barber et al. 2009).

In addition to the growth and decay of sea ice, the dynamic properties of sea ice, namely its motion, play a pivotal role in the icescape of the Arctic. In particular, open leads form when the ice pack diverges and gives rise to cracks in the ice. By contrast, pressure ridges are created when the ice pack converges. Spatially inhomogeneous ice loss in the northern hemisphere has been attributed to dynamic variability in ice export from the western to the eastern Arctic (Kwok 2008; Ogi et al. 2008). Ice advection from the Pacific to the Atlantic sectors during summer in the years 2003-2007 was found to account for a decline in summer sea ice extent ranging from $7 \%$ to $21 \%$ in 2003 and 2006, respectively, with enhanced advection in 2007. It was also shown that a persistent sea level pressure high over the Canada Basin during the 2007 summer months contributed to accelerated ice export from the Pacific to Atlantic sectors (Kwok 2008), and reduced cloudiness and enhanced downwelling radiation (Kay et al. 2008). A third record minimum in sea ice extent was observed in September 2009. Increased surface air temperature over the Canadian Arctic Archipelago during the spring of 2010 also contributed to significant ice loss in this region, while recurrence of a weakened sea level pressure atmospheric dipole pattern during the summer of 2010 resulted in a poleward retreat of sea ice in the Beaufort Sea region (NSIDC 2010). An increasingly fragile sea ice cover, associated with the loss of multi-year ice, has rendered it more susceptible to changing contributions from thermodynamic and dynamic regional atmospheric forcing mechanisms.

Circulation of the Beaufort Sea ice gyre is traditionally characterized by anticyclonic circulation, with reversals to cyclonic circulation during summer (McLaren et al. 1987; Preller and Posey 1989; LeDrew et al. 1991). Recent studies have, however, demonstrated reversals in the Beaufort Sea ice gyre throughout the annual cycle, with an increased frequency of such reversals in recent years (Lukovich and Barber 2006). Investigation of the Beaufort Sea ice gyre using 22 ice beacons launched during November 2007-May 2008 demonstrated smaller-scale features in sea ice motion in the southern Beaufort Sea (Fig. 6). Results from this analysis demonstrated the existence of distinct scaling (power) laws for zonal and meridional absolute dispersion, in addition to the nature of ocean-sea-ice-atmosphere interactions in the seasonal ice zone of the Beaufort Sea region during the 2007-2008 winter (Lukovich et al. 2011). Coherent features in sea ice motion were also depicted by loops and meanders, which were governed by local, wind-driven events in winter and non-local phenomena in spring.

The declining summer ice pack is becoming more mobile, and vulnerable to periodic cyclone-driven reversals of the Beaufort Gyre, which promotes ice divergence and may lead to increased rates of melt. Asplin et al. (2009) investigated the synoptic climatology of atmospheric forcing and its relationship to sea ice motion and reversals of the Beaufort Gyre.

Fig. 6 Trajectories of ice beacons launched during the IPY-CFL study during 07 November 2007-05 May 2008. Beacon trajectories follow anticyclonic rotation within the Beaufort Gyre, and then head westward into the Chukchi Sea

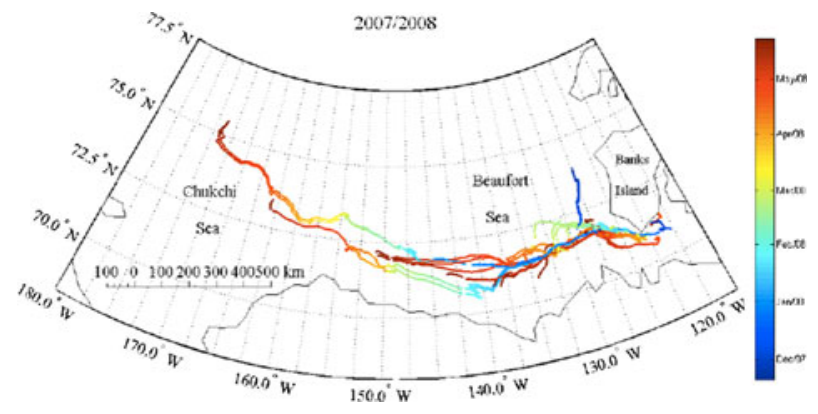


A catalogue of twelve daily synoptic weather types (Fig. 7) were generated for the Beaufort Sea region covering 1979-2008 using NCEP/NCAR reanalysis I mean sea level pressure data. The synoptic types were created using a blended technique using principal component analysis and k-means clustering, and describe the surface pressure climatology of the southern Beaufort Sea region over 1979-2008. Synoptic types 1, 6, and 7 are associated with Arctic cyclones, and all other types with anticyclones. A well-defined Beaufort High was represented by types 2 and 5 . Furthermore, types 1, 3, 4, and 8 were shown to occur during summer months; types 2, 5, 9, 10, 11, and 12 during winter months; type 6 during fall, and type 7 throughout the annual cycle.

Significant lag correlations were found between synoptic types and sea ice vorticity smoothed over a 12-week running mean and show that cyclonic types, which promote southerly or easterly atmospheric circulation over the southern Beaufort Sea, commonly precede summer reversals by anywhere from 2 to 10 weeks. As ice extent continues to decline, cyclone-driven reversals of the Beaufort Gyre may become more common throughout the year, leading to increased lead formation during the winter (Asplin et al. 2012b), and ice divergence throughout the annual cycle. This may represent a positive feedback in the summer months as increased ice divergence will decrease sea ice concentrations and areal albedo, resulting in greater absorption of downwelling solar radiation, thus increasing melt. Conversely, a negative feedback may occur in winter months when new ice, forming within leads, is easily compressed into thick ice ridges by existing ice floes, thereby increasing ice thicknesses.

Seasonal and long-term trends and variability in atmospheric circulation can be identified from the daily synoptic types. Dominant synoptic patterns for each week were identified, and clearly showed the predominance of anticyclones (cyclones) during the winter (summer).

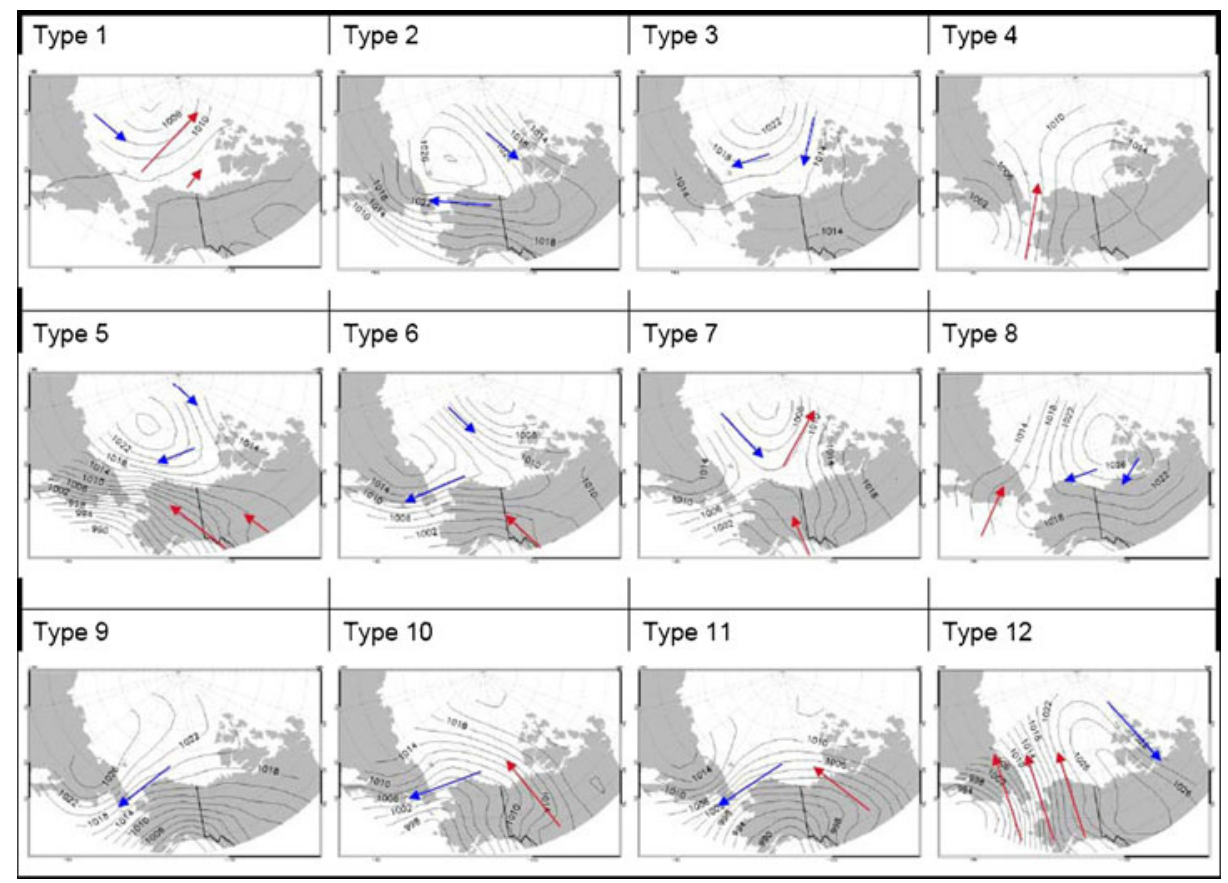

Fig. 7 The twelve synoptic types classified for the southern Beaufort Sea by Asplin et al. (2009). Arrows denote the prevailing wind forcing exerted by the sea level pressure pattern, and indicate warm (cold) temperature advection via red (blue) colouring 
Variability in the synoptic climatology of the region has also been linked to a shift in the average sea level pressure pattern over the Arctic Basin, which is attributed to the Arctic Oscillation (AO) (Thompson and Wallace 1998). The negative phase of the AO is characterized by positive SLP anomalies over the Arctic Basin, i.e., weaker cyclones and a stronger Beaufort High. The positive phase of the $\mathrm{AO}$ is characterized by negative sea level pressure anomalies in the Arctic Basin, and high sea level pressure anomalies at mid-latitudes. This characterizes stronger storms and atmospheric forcing of sea ice within the Arctic Basin. In the context of regional synoptic climatology of the southern Beaufort Sea, types 1, 4, 6, 7, and 8 exhibit increased (decreased) relative frequencies when positive (negative) AO conditions prevail (Asplin et al. 2009). Types $3,5,9,10$, and 12 show increased (decreased) relative frequencies during negative (positive) AO conditions. These findings agree with Simmonds and Keay (2009) who describe no significant trend in cyclone frequencies but noted increases in cyclone intensity throughout the Arctic Basin.

Increasingly intense cyclones and large areas of open water are showing a coupled response to climate change. Increasingly large areas of wave-generating fetch are accompanying the declining summer Arctic sea ice extent, and may result in an increase in wave energy dispersion into the pack ice. Penetration of large swells has been observed in Antarctica, causing sea ice floes to fracture into smaller floes (e.g., Steer et al. 2008). At their location within the multi-year ice (MYI), a distance of $\sim 250 \mathrm{~km}$ from the ice edge, Asplin et al. (2012a) document their observation of the initial propagation of cyclone-driven, long-wave swells into the Arctic MYI (pack-ice). These swells were generated by persistent and intense cyclone activity in the Beaufort Sea over the period 01-06 September 2009 (Fig. 8), and induced nearly instantaneous widespread fracturing of the MYI pack. The pack ice to the west of the event was heavily decayed, rotten ice (Barber et al. 2009) and this was likely key to why these swells propagated so far into the pack ice.

Cyclone forcing of large areas of open water in the Arctic Basin may lead to the development of larger-than-usual storm swells, as observed during IPY. Even the thickest MYI floes, weakened by warm summer temperatures (near freezing), may be susceptible to fracturing from storm swells. Break-up of the ice will decrease albedo (more open water), increase the lateral surface area of ice floes exposed to the ocean, and enhance melt by trapping radiation. Re-formation of sea ice in the autumn may yield a weaker ice cover that is more prone to

Fig. 8 Surface analysis chart for 00Z September, 6 2009. The cyclone affecting the Beaufort Sea is noted as a deep low centred at $\sim 140^{\circ} \mathrm{W}, 82^{\circ} \mathrm{N}$. (Image provided by the NOAA/ESRL Physical Sciences Division, Boulder Colorado from their Web site at http://www.cdc.noaa.gov/)

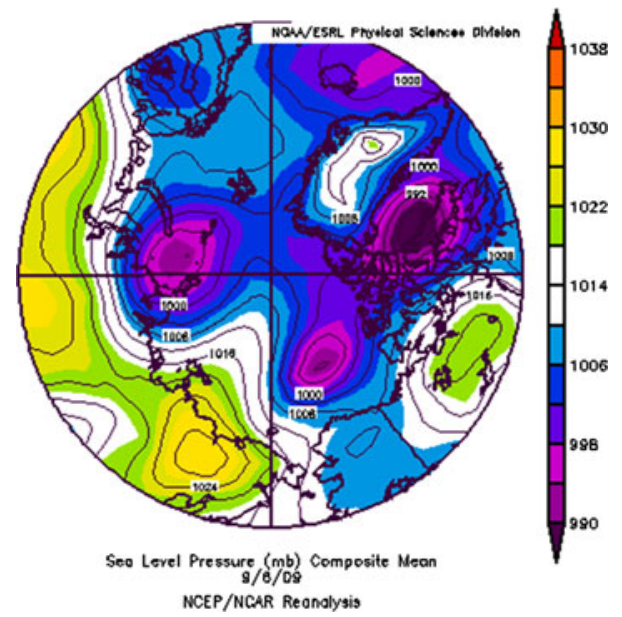


continued breakup and ridging. Enhanced ridging may act as a positive feedback (promote thicker ice), but frequent sea ice lead formation and refreezing would contribute additional heat and moisture fluxes to the atmosphere.

The vertical structure of the boundary layer is also a factor in the atmospheric forcing of sea ice. During the IPY-CFL project, a Radiometrics microwave profiling radiometer (MWRP) MP-3000AC was operated on board the research icebreaker CCGS Amundsen, and collected atmospheric boundary layer $(\mathrm{ABL})$ profiles of temperature $\left({ }^{\circ} \mathrm{K}\right)$, and absolute

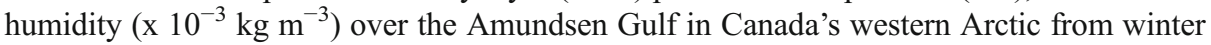
to the summer 2008. A comparison of these profiles to concurrent radiosonde data found these profiles to be reliable from the surface up to 1500-2000 $\mathrm{m}$ in the ABL (Candlish et al. 2012). Raddatz et al. (2011) described the general characteristic of the ABL based on the time series of hourly MWRP soundings. Both the median winter (JFM) and median spring (AMJ) ABL potential temperature profiles had a shallow (surface to $350 \mathrm{~m}$ ) thermal internal boundary layer (IBL) topped by an elevated inversion (350 to $1000 \mathrm{~m}$ in winter and 350 to $800 \mathrm{~m}$ in spring). The presence of an IBL was attributed solely to convective turbulence, and not to shear-induced mixing.

In a follow-up paper, Raddatz et al. (2012) explored the link between the sea ice cover of the Amundsen Gulf and the overlying atmospheric boundary layer on a weekly time-step from winter to summer 2008. The total sea ice cover exhibited little variation from 7 January to 21 April (around $97 \%$ sea ice cover with $3 \%$ leads). From 28 April to 12 May, the total sea ice cover approached $100 \%$. From May 19, the total sea ice cover declined rapidly to its July minimum of about $3 \%$. During the winter, a thermal internal boundary layer was present in 10 of the 12 mean daily temperature profiles. The average depth was $375 \mathrm{~m}$ below a radiation inversion which extended to about $1100 \mathrm{~m}$. This profile is consistent with the typical vertical thermal structure over Arctic sea ice described by Overland and Guest (1991). The thermal IBL was attributed to the mesoscale upward flux of sensible heat (range 17.0 to $70.7 \mathrm{Wm}^{-2}$; mean $=45.7 \mathrm{Wm}^{-2}$ ) from the mosaic surface of the Amundsen Gulf (thick $[>0.3 \mathrm{~m}]$ sea ice with a persistent inter-ice-pan lead network of open water or new and young sea ice [thin ice $\leq 0.3 \mathrm{~m}$ ]) whose area-averaged surface temperature was generally higher than the near surface temperature of the approaching air mass. A thermal IBL was also present in 8 of 9 early spring mean daily profiles; however, surface fluxes were not estimated for this period. During late spring and early summer, a stable IBL was present in 7 of the 8 temperature profiles. The average depth was $250 \mathrm{~m}$ below a residual mixing layer which extended to about $700 \mathrm{~m}$. The stable IBL was attributed to the mesoscale downward flux of sensible heat (range -1.6 to $-45.1 \mathrm{Wm}^{-2}$; mean $=-18.8 \mathrm{Wm}^{-2}$ ) to the extensive open water surface of the Amundsen Gulf (sea ice cover declined to about $3 \%$ in July) where the area-averaged surface temperature was generally lower than the near-surface temperature of the approaching air mass. The presence of an IBL, which was common from winter through summer 2008, indicated that the surface layer of the atmosphere was responding to the unconsolidated pack ice with its persistent inter-ice-pan lead network in winter and early spring, and to the cold sea surface in late spring and summer following break-up. However, during the Arctic night, the elevated inversion above the IBL buffered the surface layer, and the sea ice surface from the free atmosphere. The stable upper portion of the ABL would dampen the turbulent exchange of sensible and latent heat between the free atmosphere and the surface. This thermal profile could also lead to a large vertical wind shear with minimal downward momentum transfer between the synoptic winds of the free atmosphere and the sea ice. During the summer, the stable IBL promoted the downward flux of sensible and latent heat to the sea ice surface, but it inhibited the elevated mixing layer, which may be responding to free atmosphere advection, from imparting heat or momentum to the sea icescape. 


\section{Conclusions}

The research results from the Canadian IPY program describe the breadth and depth of the coupling between the sea icescape and the processes which act on this icescape. The results within this paper can be used in the assessment and future prediction of sea ice regimes in the Arctic Basin. Many interrelated sea ice physical processes and characteristics should be considered by policy makers including, but not limited to: sea ice divergence/convergence, changes in sea ice motion, and reduced seasonal ice cover. This will have implications for local community members and their use of the sea ice for hunting and transportation activities. These implications extend Arctic-wide, affecting commercial shipping, navigation, and aspects of the ecosystem including harvesting of polar bears, transport of nutrients, and the contaminant pathways in this system.

The significant reduction in sea ice extent and thickness already has important implications for northern coastal communities. An increase in storm surges resulting from the reduction in sea ice extent and duration in coastal regions has increased coastal erosion, precipitated the moving of human infrastructure and affected fishing and other harvesting activities (Perrie et al. 2012). Changing seasonal sea ice extent and timing of freeze-up and breakup affect the safety and efficiency of transportation by residents and hunters in northern communities, and the food security of residents throughout the annual cycle. The demands imposed by the physical factors of climate change need to be addressed in the context of socio-economic factors and globalization (ACIA 2005; IRPP 2009) to ensure adaptability of northern communities.

Ice variability and loss, and changes in sea ice flux between the Arctic Ocean, Baffin Bay and the Canadian Arctic Archipelago, have important implications for transportation in the Arctic. Once largely inaccessible to commercial shipping, the Northwest Passage has been mostly seasonally ice-free since 2007. Due to warm spring temperatures and increased loss of multiyear ice (NSIDC 2010) the Northwest Passage experienced a record reduction in sea ice in August 2010. This has important and significant implications for seasonal shipping, industrial development, navigation, and Canadian Arctic sovereignty.

\section{Looking ahead}

As illustrated in this review, the Arctic sea icescape is currently in rapid transition. The icescape now consists of a small proportion of multi-year sea ice and a correspondingly large proportion of annual ice. The timing of ice formation and decay has also changed as have the rates of these changes. Both the ice type and its geophysical state have significant implications for how the physical system evolves in the Arctic and how the marine ecosystem, contaminant transport and human use of these icescapes evolve. Furthermore, the interface between northern communities and Arctic science programs needs to be strengthened through activities such as community-based monitoring, so that traditional knowledge can be appropriately captured in the future as the climate of the Arctic continues to change. In particular, community-based monitoring can integrate directly with western science within national and international observing programs such as the Sustaining Arctic Observing Networks (SAON) initiative of the Arctic Council and the International Arctic Science Committee (IASC). The momentum of IPY-generated Arctic science will strengthen Canadian leadership in polar science as well as the data and understanding required for sustainable development of Arctic resources and stewardship of the Arctic environment in this time of unprecedented change. 
Acknowledgments Funding for the IPY-CFL project was provided by the Canadian International Polar Year (IPY) Federal Program Office, the Natural Sciences and Engineering Research Council (NSERC), the Canada Research Chairs (CRC) Program, Canada Foundation for Innovation (CFI), and numerous international partner organizations. Special thanks to the officers and crew of the CCGS Amundsen, whose dedication and excellence made the IPY-CFL project a unique milestone in polar marine science. Special thanks go out to the numerous community members of Sachs Harbour, Ulukhaktok, and Paulatuk for participating in the traditional knowledge study. Thanks also to Chris Furgal, Pitsey Moss Davies and Jenny Knopp for contributions to the traditional knowledge section of this paper.

Open Access This article is distributed under the terms of the Creative Commons Attribution License which permits any use, distribution, and reproduction in any medium, provided the original author(s) and the source are credited.

\section{References}

ACIA (Arctic Climate Impact Assessment) (2005) Arctic climate impact assessment: Scientific report. University of Cambridge Press, Cambridge

Agnew T, Lambe A, Long D (2008) Estimating sea ice area flux across the Canadian Arctic Archipelago using enhanced AMSR-E. J Geophys Res 113:C10011. doi:10.1029/2007JC004582

Asplin MG, Lukovich JV, Barber DG (2009) Atmospheric forcing of the Beaufort Sea ice gyre: Part I: Surface pressure climatology and sea ice motion. J Geophys Res. doi:10.1029/2008JC005127

Asplin MG, Galley RJ, Barber DG, Prinsenberg S (2012a; in review) Fracture of summer perennial sea ice by ocean swell as a result of Arctic storms. J Geophys Res

Asplin MG, Candlish L, Galley RJ, Raddatz RL, Barber DG (2012b; in review) Cyclone forced lead formation and ocean-sea ice-atmosphere coupling within a flaw lead region. J Geophys Res

Barber DG, Barber D (2009) Two Ways of Knowing: Merging Science and Traditional Knowledge During the Fourth International Polar Year, University of Manitoba Press. ISBN. 978-0-9813265-0-4, pp. 287

Barber DG, Lukovich JV (2011) Sea ice in Canada. In: French H, Slaymaker O (eds) Changing cold environments - a Canadian perspective, Wiley-Blackwell, pp. 321

Barber DG, Marsden R, Minnett P, Ingram G, Fortier L (2001) Physical processes within the North Water (NOW) Polynya. Atmos-Ocean 39(3):163-166. doi:10.1080/07055900.2001.9649673

Barber DG, Galley R, Asplin MG, De Abreau R, Warner KA et al (2009) Perennial pack ice in the southern Beaufort Sea was not as it appeared in the summer of 2009. Geophys Res Lett 36:L24501. doi:10.1029/ 2009GL041434

Barber DG, Asplin M, Gratton Y, Lukovich J, Galley R et al (2010) The International Polar Year (IPY) Circumpolar Flaw Lead (CFL) System Study: introduction and physical system. Atmos-Ocean 48 (4):225-243. doi:3137/OC317.2010

Barber DG, Asplin MG, Papakyriakou T, Miller L, Iacozza J et al (2012; this issue) Consequences of change and variability in sea ice during the 2007-2008 Canadian International Polar Year program. Clim Change

Budikova D (2009) Role of Arctic sea ice in global atmospheric circulation: a review. Glob Planet Change 68:149-163

Candlish L, Raddatz RL, Asplin MG, Barber DG (2012; in review) Veracity of atmospheric temperature and absolute humidity profiles over the Beaufort Sea and Amundsen Gulf from a microwave radiometer. J Atmos Ocean Tech (in review)

Comiso JC (2003a) Warming trends in the Arctic from clear-sky satellite observations. J Climate 16:3498-3510

Comiso JC (2003b) Chapter 4: large-scale characteristics and variability of the global sea ice cover. In: Thomas D, Diekmann G (eds) Sea ice: an introduction to its physics, chemistry, biology and geology. Blackwell Scientific, Oxford, pp 112-142

Comiso JC (2006) Abrupt decline in the Arctic winter sea ice cover. Geophys Res Lett L18504. doi:10.1029/ 2006GL027341

Derksen C, Smith SL, Sharp M, Brown L, Howell S et al (2012) Variability and change in the Canadian cryosphere. Clim Change (this issue)

Deser C, Teng H (2008) Evolution of Arctic sea ice concentration trends and the role of atmospheric circulation forcing, 1979-2007. Geophys Res Lett 35:L02504. doi:10.1029/2007GL032023

Fequet D (ed) (2002) MANICE: Manual of Standard Procedures for Observing and Reporting Ice Conditions, 9th ed., Can. Ice Serv., Environ. Can., Ottawa 
Galley RJ, Key E, Barber DG, Hwang BJ, Ehn JK (2008) Spatial and temporal variability of sea ice in the southern Beaufort Sea and Amundsen Gulf: 1980-2004. J Geophys Res 113:C05S95. doi:10.1029/ 2007JC004553

Haas C, Pfaffling A, Hendricks S, Rabenstein L, Etienne J-L et al (2008) Reduced ice thickness in Arctic Transpolar Drift favors rapid ice retreat. Geophys Res Lett 35:L17501. doi:10.1029/2008GL034457

Hansen J, Russell G, Rind D, Stone P, Lacis A, Lebedeff S, Ruedy R, Travis L (1983) Efficient threedimensional global models for climate studies: Models I and II. Mon Weather Rev 111:609-662. doi:10.1175/1520-0493(1983)111<0609:ETDGMF>2.0.CO;2

Hochheim KP, Barber DG (2010) Atmospheric forcing of sea ice in Hudson Bay during the fall period, 1980-2005. J Geophys Res 115:C05009. doi:10.1029/2009JC005334

Hochheim KP, Lukovich JV, Barber DG (2011) Atmospheric forcing of sea ice in Hudson Bay during the spring period, 1980-2005. J Mar Syst 88(3):476-487

Howell SEL, Tivy A, Yackel JJ, Else BGT, Duguay CR (2008) Changing sea ice melt parameters in the Canadian Arctic Archipelago: implications for the future presence of multiyear ice. J Geophys Res 113: C09030. doi:10.1029/2008JC004730

Howell SEL, Duguay CR, Markus T (2009) Sea ice conditions and melt season duration variability within the Canadian Arctic Archipelago: 1979-2008. Geophys Res Lett 36:L10502. doi:10.1029/2009GL037681

Howell SEL, Tivy A, Agnew T, Markus T, Derksen C (2010) Extreme low sea ice years in the Canadian Arctic Archipelago: 1998 versus 2007. J Geophys Res 115:C10053. doi:10.1029/2010JC006155

Inoue J, Hori ME (2011) Arctic cyclogenesis at the marginal ice zone: a contributory mechanism for Arctic amplification? Geophys Res Lett 38:L12502. doi:10.1029/2011GL047696

Institute for Research on Public Policy (IRPP) (2009) Volume IV, Northern Exposure: Peoples, Powers and Prospects in Canada's North. In: Abele F, Courchene T, Seidle F, St-Hilaire F (eds) National Library of Canada

Intergovernmental Panel on Climate Change (IPCC) (2007) Climate change 2007: The scientific basis. Contribution of Working Group I to the Third Assessment Report of the Intergovernmental Panel on Climate Change. Cambridge: Cambridge University Press

Kay JE, L'Ecuyer T, Gettelman A, Stephens G, O'Dell C (2008) The contribution of cloud and radiation anomalies to the 2007 Arctic sea ice extent minimum. Geophys Res Lett 35:L08503. doi:10.1029/ 2008GL033451

Kinnard C, Zdanowicz CM, Fisher DA, Isaksson E, de Vernal A et al (2011) Reconstructed changes in Arctic sea ice over the past 1,450 years. Nature. doi:10.1038/nature 10581

Kwok R (2008) Summer sea ice motion from the $18 \mathrm{GHz}$ channel of AMSR-E and the exchange of sea ice between the Pacific and Atlantic sectors. Geophys Res Lett 35:L03504. doi:10.1029/2007GL032692

Kwok R, Cunningham GF, Wensnahan M, Rigor I, Zwally HJ et al (2009) Thinning and volume loss of the Arctic Ocean sea ice cover: 2003-2008. J Geophys Res 114:C07005. doi:10.1029/2009JC005312

Lammers RB, Shiklomanov AI, Vorosmarty CJ, Fekete BM, Peterson BJ (2001) Assessment of contemporary Arctic river runoff based on observation discharge records. J Geophys Res 106(D4):3321-3334

LeDrew EL, Johnson D, Maslanik JA (1991) An examination of atmospheric mechanisms that may be responsible for the annual reversal of the Beaufort Sea ice field. Int J Climatol 11:841-859

Laxon S, Peacock N, Smith D (2003) High interannual variability of sea ice thickness in the Arctic region. Nature 425:947-950

Lindsay RW, Zhang J (2005) The thinning Arctic sea ice, 1988-2003: have we passed a tipping point? J Climate 18(22):4879-4894

Lukovich JV, Barber DG (2006) Atmospheric controls on sea ice motion in the southern Beaufort Sea. J Geophys Res 111:D18103. doi:10.1029/2005JD006408

Lukovich JV, Babb DG, Barber DG (2011) Ice beacon trajectories in the Arctic during the IPY-CFL study. J Geophys Res. doi:10.1029/2011JC007049

Maslanik JA, Fowler C, Stroeve J, Drobot S, Zwally J et al (2007) A younger, thinner Arctic ice cover: increased potential for rapid, extensive sea-ice loss. Geophys Res Lett 34:L24501. doi:10.1029/2007GL032043

Maslanik J, Stroeve J, Fowler C, Emery W (2011) Distribution and trends in Arctic sea ice age through spring (2011). Geophys Res Lett 38:L13502. doi:10.1029/2011GL047735

McLaren AS, Serreze MC, Barry RG (1987) Seasonal variations of sea ice motion in the Canada basin and their implications. Geophys Res Lett 114:1123-1126

Ngheim SV, Rigor IG, Perovich DK, Clemente-Colón P, Weatherly JW et al (2007) Rapid reduction of Arctic perennial sea ice. Geophys Res Lett 34:L19504. doi:10.1029/2007GL031138

(NSIDC) (2009) National Snow and Ice Data Centre: What is sea ice? http://nsidc.org/seaice/intro.html

(NSIDC) (2010) National Snow and Ice Data Centre, Sea Ice News: http://nsidc.org/arcticseaicenews/index.html

(NSIDC) (2011) National Snow and Ice Data Centre, Sea Ice News: http://nsidc.org/arcticseaicenews/2011/09/

Ogi M, Rigor IG, McPhee MG, Wallace JM (2008) Summer retreat of Arctic sea ice: role of summer winds. Geophys Res Lett 35:L24701. doi:10.1029/2008GL035672 
Overland JE (2009) Meteorology in the Beaufort Sea. J Geophys Res 114:C00A07. doi:10.1029/2008JC004861

Overland JE, Guest PS (1991) The Arctic snow and air temperature budget over sea ice during winter. J Geophys Res 96:4651-4662

Overland JE, Wang M, Salo S (2008) The recent Arctic warm period. Tellus 60A:589-597

Parkinson CL, Cavalieri D (2008) Arctic sea ice variability and trends, 1979-2006. J Geophys Res 113: C07003. doi:10.1029/2007JC004558

Perovich DK, Richter-Menge JA, Jones KF, Light B (2008) Sunlight, water, and ice: extreme Arctic sea ice melt during the summer of (2007). Geophys Res Lett 35:L11501. doi:10.1029/2008GL034007

Perrie W, Long Z, Hung H, Cole A, Steffen A et al (2012) Selected topics in Arctic atmosphere and climate. Clim Change (this issue)

Peterson IK, Prinsenberg SJ, Holladay JS (2008) Observations of sea ice thickness, surface roughness and ice motion in Amundsen Gulf. J Geophys Res 113:C06016. doi:10.1029/2007JC004456

Preller R, Posey P (1989) A numerical model simulation of a summer reversal of the Beaufort Gyre. Geophys Res Lett 16(1):doi: 10.1029/88GL04100

Raddatz RL, Asplin MG, Candlish L, Barber DG (2011) General characteristics of the atmospheric boundary layer in a flaw lead Polynya Region for winter and spring. Boundary-Layer Meteorol. doi:10.1007/ s10546-010-9557-1

Raddatz RL, Gallet RJ, Barber DG (2012) Linking the atmospheric boundary layer to the Amundsen Gulf sea-ice cover: a mesoscale to synoptic-scale perspective from winter to summer 2008. doi: 10.1007/s10546-011-9669-2

Rothrock DA, Yu Y, Maykut GA (1999) Thinning of the Arctic sea-ice cover. Geophys Res Lett 26(23):3469-3472

Saucier FJ, Senneville S, Prinsenberg S, Roy F, Smith G et al (2004) Modelling the sea ice-ocean seasonal cycle in Hudson Bay, Foxe Basin and Hudson Strait, Canada. Clim Dynam 23:303-326

Segtnan OH, Furevik T, Jenkins AD (2011) Heat and freshwater budgets of the Nordic Seas computed from atmospheric reanalysis and observations. J Geophys Res C: Oceans 116:C11003. doi:10.1029/2011JC006939

Simmonds I, Keay K (2009) Extraordinary September Arctic sea ice reductions and their relationships with storm behavior over 1979-2008. Geophys Res Lett 36:L19715. doi:10.1029/2009GL039810

Steer A, Worby A, Heil P (2008) Observed changes in sea-ice floe distribution during early summer in the Western Weddell Sea. Deep Sea Res II:933-942

Tang C, Dunlap E (2007) Modeling annual variation of sea-ice cover in Baffin Bay. Int J Offshore Polar Eng 17(3):176-181

Thompson DWJ, Wallace JM (1998) The Arctic oscillation signature in wintertime geopotential height and temperature fields. Geophys Res Lett 25:1297-1300

Tivy A, Howell SEL, Alt B, McCourt S, Chagnon R, Crocker G, Carrieres T, Yackel JJ (2011) Trends and variability in summer sea ice cover in the Canadian Arctic based on the Canadian Ice Service Digital Archive, 1960-2008, and 1968-2008. J Geophys Res 116:C03007. doi:10.1029/2009JC005855

Woodgate RA, Aagaard K, Weingartner TJ (2006) Interannual changes in the Bering Strait fluxes of volume, heat and freshwater between 1991 and 2004. Geophys Res Lett 33:L15609. doi:10.1029/2006GL026931

Yu Y, Maykut GA, Rothrock DA (2004) Changes in the thickness distribution of Arctic sea ice between 19581970 and 1993-1997. J Geophys Res 109:C08004. doi:10.1029/2003JC001982

Zhang J (2005) Warming of the Arctic ice-ocean system is faster than the global average since the 1960s. Geophys Res Lett 32:L19602. doi:10.1029/2005GL024216

\section{Internet/Web Sources}

ArcticNet, A Canadian Network of Centres of Excellence: http://www.arcticnet.ulaval.ca/ Canadian Ice Service (CIS): http://www.ec.gc.ca/glaces-ice/default.asp?lang=En\&n=19CDA64E-1 International Polar Year Circumpolar Flaw Lead (IPY-CFL) polynya study: http://www.ipy-cfl.ca/ NASA: http://earthobservatory.nasa.gov/Features/WorldOfChange/sea_ice.php National Snow and Ice Data Centre (NSIDC): http://nsidc.org/seaice/intro.html National Snow and Ice Data Centre (NSIDC): http://nsidc.org/arcticseaicenews.html

NOW, the North Water Polynya Project, 2001, International North Water Polynya Study: http://www2.fsg. ulaval.ca/giroq/now//wel.htm.

U. S. Climate Change Science Program: http://climatescience.gov

Wadhams P (2003) How does Arctic sea ice form and decay? http://www.arctic.noaa.gov/essay_wadhams.html 